NBER WORKING PAPER SERIES

\title{
THE EVOLUTION OF TOP INCOMES: A HISTORICAL AND INTERNATIONAL PERSPECTIVE
}

\author{
Thomas Piketty \\ Emmanuel Saez \\ Working Paper 11955 \\ http://www.nber.org/papers/w11955 \\ NATIONAL BUREAU OF ECONOMIC RESEARCH \\ 1050 Massachusetts Avenue \\ Cambridge, MA 02138 \\ January 2006
}

PSE, 48 Boulevard Jourdan, 75014 Paris, France, and University of California, Department of Economics, 549 Evans Hall \#3880, Berkeley, CA 94720, respectively. We thank Tony Atkinson, Lawrence Katz, and conference participants at the 2006 AEA meetings for helpful discussions and comments. Financial support from NSF Grant SES-0134946 and the MacArthur foundation is gratefully acknowledged. The views expressed herein are those of the author(s) and do not necessarily reflect the views of the National Bureau of Economic Research.

(C2006 by Thomas Piketty amd Emmanuel Saez. All rights reserved. Short sections of text, not to exceed two paragraphs, may be quoted without explicit permission provided that full credit, including $\odot$ notice, is given to the source. 
The Evolution of Top Incomes: A Historical and International Perspective Thomas Piketty amd Emmanuel Saez

NBER Working Paper No. 11955

January 2006

JEL No. D3, J3

\begin{abstract}
This paper summarizes the main findings of the recent studies that have constructed top income and wealth shares series over the century for a number of countries using tax statistics. Most countries experience a dramatic drop in top income shares in the first part of the century due to a precipitous drop in large wealth holdings during the wars and depression shocks. Top income shares do not recover in the immediate post war decades. However, over the last 30 years, top income shares have increased substantially in English speaking countries but not at all in continental Europe countries or Japan. This increase is due to an unprecedented surge in top wage incomes starting in the 1970s and accelerating in the 1990s. As a result, top wage earners have replaced capital income earners at the top of the income distribution in English speaking countries. We discuss the proposed explanations and the main questions that remain open.

Thomas Piketty

PSE

48 Boulevard Jourdan

75014 Paris

France

piketty@ens.fr

Emmanuel Saez

Department of Economics

University of California, Berkeley

549 Evans Hall, \#3880

Berkeley, CA 94720

and NBER

saez@econ.berkeley.edu
\end{abstract}


This paper summarizes the main findings and perspectives emerging from a collective research project on the dynamics of income and wealth distribution. The primary objective of this project is to construct a high-quality, long run, international data base on income and wealth concentration using historical tax statistics. The resulting database now includes annual series covering most of the $20^{\text {th }}$ century for a number of (mostly Western) countries. ${ }^{1}$

The main motivation for this project comes from a general dissatisfaction with existing income inequality databases. Existing international databases display little homogeneity over time or across countries), they cover only a few isolated years per country, generally restricted to the post-1970 or post-1980 period. They almost never offer any decomposition of income inequality into a labor income and a capital income component. Economic mechanisms can be very different for the distribution of labor income (demand and supply of skills, labor market institutions, etc.) and the distribution of capital income (capital accumulation, credit constraints, inheritance law and taxation, etc.), so that it is difficult to test any of these mechanisms using existing data. The fact that existing data are not long run is also problematic, because structural changes in income and wealth distributions often span over several decades. In order to properly understand such changes, one needs to be able to put them into broader historical perspective.

Although our database also suffers from important limitations (in particular, our long-run series are generally confined to top income and wealth shares and contain little information about bottom segments of the distribution), they are fairly homogenous across countries, annual, long-run, and broken down by income source. Hence they offer a unique opportunity to better understand the dynamics of income and wealth distribution and the interplay between inequality and growth.

The rest of this paper is organized as follows. In section 1, we present the basic methodology used to construct the database. Section 2 presents the main descriptive findings. Section 3 discusses the main interpretations that have been put forward to account for the facts.

\section{Constructing a New Data Base}


Household income surveys virtually did not exist prior to 1950 . The only data source that is consistently available on a long-run basis is tax data. Most Western countries published annual tax statistics since the beginning of income taxation, in general about a century ago. Those statistics generally report for a large number of income brackets the corresponding number of taxpayers, as well as their total income and tax liability. Those statistics usually provide the break down by income source: capital income, wage income, business income, etc. Using population census data, one can estimate the total number of tax units had everybody been required to file a tax return and hence determine the number of returns in top fractile groups such as the top $10 \%$, top $1 \%$, etc. One can then use standard Pareto interpolation techniques to compute thresholds and average incomes corresponding to each of those top groups. Top income shares series are obtained by dividing top income series by total personal income. This denominator can be computed using aggregate income sources (national accounts and their ancestors). ${ }^{2}$ The denominator is adjusted to represent as closely as possible total personal income reported on tax returns had everybody been required to file. There are two important limitations with such data.

First, prior to World War II, in most countries, the proportion of individuals subject to progressive income taxation rarely exceeded $10 \%$, so that one can only compute top decile income share series (and above) over the entire period.

Second, the data are based on income reported for tax purposes. As a result, the data might not reflect real income because of tax evasion (fraudulent under-reporting or non reporting) or tax avoidance (using legal means to repackage reported incomes in order to reduce tax liability). The extent of tax evasion or tax avoidance is possibly related to the level of taxes, the enforcement of the tax law, and to the legal tax environment. Therefore, when using tax data to study top incomes, it is necessary to analyse the tax structure at the same time in order to tell apart real changes in income concentration from changes due to tax avoidance or evasion following a tax reform. This aspect is likely to be even more important in the case of 
developing countries where tax enforcement is weaker and tax avoidance and evasion is likely to be a key determinant of reported top incomes.

\section{Top Income Shares results}

Figure 1, Panel A, presents the income share of the top decile from 1917 to 2002 in the United States. The overall pattern of the top decile share over the century is U-shaped. The share of the top decile fluctuates around $40-45 \%$ during the interwar period. It declines substantially to just above $30 \%$ in four years during World War II and stays flat at $31-32 \%$ until the 1970 s. Such an abrupt decline cannot easily be reconciled with a Kuznets type process. After decades of stability in the post war period, the top decile share has increased dramatically over the last 25 years is now at a level close to the pre-war level.

Figure 1, Panel B decomposes the top decile into the top percentile (top 1\%) and the next $4 \%$ (top 5-1\%), and the bottom half of the top decile (top 10-5\%). Interestingly, most of the fluctuations of the top decile are due to fluctuations within the top percentile. The drop in the next two groups during World War II is far less dramatic and they recover from the WWII shock relatively quickly. Finally, their shares do not increase much during in the recent decades. In contrast, the top percentile has gone through enormous fluctuations along the course of the $20^{\text {th }}$ century, from about $18 \%$ before WWI to only about $8 \%$ during the 1960 s-1970s, and back to almost $17 \%$ by 2000 . The top percentile share declined during WWI, recovered during the 1920s boom, and declined again during the great depression and WWII. This very specific timing, together with the fact that very high incomes account for a disproportionate share of the total decline in inequality, strongly suggests that the shocks incurred by capital owners during 1914 to 1945 (depression and wars) have played a key role. ${ }^{3}$

Indeed, looking at very top incomes and their composition provides additional evidence on this. Figure 2 displays the share and composition of income from 1916 to 2000 for the top $0.01 \%$ group in the United States. Up to the 1970s, very top incomes were mostly composed of capital income (mostly dividend income) and to a smaller extent of business income, the wage 
income share being very modest. Figure 2 confirms that the large decline of top incomes observed during the $1914-1960$ period is predominantly a capital income phenomenon.

Figure 2 shows that the income composition pattern at the very top has changed considerably between 1960 and 2000. Salary income has been driving up top incomes and has now become the main source of income at the very top. The dramatic evolution of the composition of top incomes seems robust. First, National Accounts data show that the share of capital income in aggregate personal income has been stable in the long-run. Therefore, the secular decline of top capital incomes is the consequence of a decreased concentration of capital income and not of a decline in the share of capital income in the economy as a whole. Second, estimates of wealth concentration constructed by Wojciech Kopczuk and Emmanuel Saez (2004) from estate tax returns for the 1916-2000 period in the United States show a precipitous decline in the first part of the century with only very modest increases in recent decades (see Figure 4, Panel B below). This evidence is consistent with the income share series, and shows that the dramatic recent increase in income concentration is a primarily a labor income phenomenon and this has not yet translated into a dramatic increase in wealth concentration.

The dramatic decline in top income shares in the first part the 20th century took place in almost all countries that have been studied. Figure 3 , Panel A, displays the top $0.1 \%$ income share in three English speaking countries (panel A): the United States, the United Kingdom, and Canada. Panel B displays the top $0.1 \%$ for France and Japan. All countries experience a sharp drop in the first part of the century. The timing and size of the decline varies across countries. For example, the decline in Japan is entirely concentrated in the immediate pre-war and the war years. ${ }^{4}$ As in the United States, income composition series for each of those countries shows that this decrease is primarily a capital income phenomenon due to the fall of top capital incomes.

Figure 3 shows a sharp contrast between English speaking countries and other countries in recent decades. The United States, Canada, and the United Kingdom display a substantial increase in the top $0.1 \%$ income share 
over the last 25 years. This increase is largest in the United States, but the timing is remarkably similar across the three countries. In contrast, France and Japan do not experience any noticeable increase in the top $0.1 \%$ income share in recent decades. As a result, as of today, income concentration is much lower in those three countries than in the English speaking countries.

\section{Explaining the results and future research}

The fact that the drop in income concentration in the first part of the $20^{\text {th }}$ century is primarily due to the fall in top capital incomes, and that the fall took place mostly during wartime and the Great Depression in most of those countries, suggests an obvious explanation. For the most part, income inequality dropped because capital owners incurred severe shocks to their capital holdings during the 1914-1945 period such as destructions, inflation, bankruptcies, and fiscal shocks for financing the wars. This interpretation is confirmed by available wealth and estate data for countries such as France, the United States, or Japan. Note that the idea that capital owners incurred large shocks during the 1914-1945 period and that this had a big impact on income distribution is certainly not new (Kuznets already metioned this factor). What is new is that there is not much else going on.

The more challenging part that needs to be explained is the nonrecovery of top capital incomes during the post-1945 period. The proposed explanation is that the 1914-1945 capital shocks had a permanent impact because the introduction of progressive income and estate taxation (there was virtually no tax progressivity prior to 1914, and top rates increased enormously between 1914 and 1945) made it impossible for top capital holders to fully recover. Simple simulations suggest that the long-run impact of tax progressivity on wealth concentration is indeed large enough to explain the magnitude of the observed changes (see Thomas Piketty, 2003).

Those explanations about the dynamics of capital income concentration could possibly be tested by looking at the case of countries which either did not experience large pre-1945 shocks and/or did not implement significant and sustained progressive income tax systems. Switzerland stayed out of the wars and never implemented very progressive 
wealth or income taxation. Fabien Dell, Thomas Piketty, and Emmanuel Saez (2006) estimate top income and wealth shares for Switzerland. As displayed on Figure 4, in contrast to other countries such as the United States, top wealth shares in Switzerland hardly declined from 1913 to the 1960s.

To make further progress, it would be interesting to consider (1) countries which avoided the war or depression shocks but developed progressive taxation, such as Ireland and Sweden (2) countries which experienced the shocks but did not develop progressive taxation. Unfortunately, no European country falls clearly into this latter category. ${ }^{5}$ Brian Nolan (2006) shows that there was no significant drop in top income shares in Ireland during World War II and that top income shares were quite similar in the early 1920s and the late 1940s. However, top income shares did fall significantly in the post war decades when Ireland implemented progressive taxation with very high top rates. Those results suggest that the large war shocks may not be necessary to drive down top income shares and that the change in the tax structure might be the most important determinant of long-run income concentration. In future work, it should be possible to develop precise series of tax burdens by income fractiles and income sources for each country and use regression analysis in order to provide more convincing tests of those explanations. Other factors such as fertility, or the norms about estate division between heirs could also have significant impacts on the long-run wealth distribution.

During the post-1970 period, one does observe a major divergence between rich countries. While top income shares have remained fairly stable in Continental European countries or Japan over the past three decades, they have increased enormously in the United States and other English speaking countries (Figure 3). This rise of top income shares is not due to the revival of top capital incomes, but rather to the very large increases in top wages (especially top executive compensation). As a consequence, top executives (the "working rich") have replaced top capital owners (the "rentiers") at the top of the income hierarchy over the course of the $20^{\text {th }}$ century. Understanding why top wage have surged in English speaking countries in recent decades but not in continental Europe or Japan remains a controversial question, with three broad views. First, the free market view (e.g., Murphy and Zabojnik, 
2004) claims that technological progress has made managerial skills more general and less firm specific, hence increasing competition for the best executives from segregated within firm markets to a single economy wide market. While this view can possibly account for US trends, it cannot explain why executive pay has not changed in other countries such as Japan or France, which have gone through similar technological changes. A second view claims that impediments to free markets due to labor market regulations, unions, or social norms regarding pay inequality, can keep executive pay below market. Such impediments have been largely removed in the United States but still exist in Europe or Japan, explaining the trends. Under this view, the surge in executive compensation actually represents valuable efficiency gains. Finally, a third view claims that the surge in top compensation in the United States is due to an increased ability of executives to set their own pay and extract rents at the expense of shareholders perhaps for the same reasons as under the second view. However, in this case, there might not be any efficiency gains associated.

Finally, the relationship that one might want to test ultimately using our database is the impact of inequality on growth. Casual examination of the series constructed suggests that income concentration and growth are not systematically related. Many countries (such as France, the United States, or Japan) grew fastest in the post war decades when income concentration was at its lowest. So, one can safely conclude that the enormous decline in wealth concentration that took place between 1914 and 1945 did not prevent high growth from happening. However, it seems that in recent decades, growth and increases in inequality have been positively correlated: the United States and the United Kingdom have grown faster than continental Europe or Japan. ${ }^{6}$ Although cross-country analysis will always suffer from severe identification problems, our hope is that the database we have constructed will renew the analysis of the interplay between inequality and growth. 


\section{REFERENCES}

Atkinson, Anthony. "Top Incomes in the United Kingdom over the Twentieth Century," in A. B. Atkinson and T. Piketty, eds., Top Incomes over the Twentieth Century, Oxford: Oxford University Press, 2006.

Atkinson, Anthony and Piketty, Thomas. Top Incomes over the Twentieth Century. Oxford: Oxford University Press, 2006.

Dew-Becker, lan and Gordon, Robert. "Where Did the Productivity Growth Go? Inflation Dynamics and the Distribution of Income." NBER Working Paper, No. 11842, December 2005.

Dell, Fabien. "Top Incomes in Germany throughout the Twentieth Century: 1891-1998," in A. B. Atkinson and T. Piketty, eds., Top Incomes over the Twentieth Century, Oxford: Oxford University Press, 2006.

Dell Fabien, Thomas Piketty, and Saez, Emmanuel. "The Evolution of Income and Wealth Concentration in Switzerland over the 20th Century," in A. B. Atkinson and T. Piketty, eds., Top Incomes over the Twentieth Century, Oxford: Oxford University Press, 2006.

Kopczuk, Wojciech and Saez, Emmanuel. "Top Wealth Shares in the United States, 1916-2000: Evidence from Estate Tax Returns." National Tax Journal, June 2004, 57(2), Part 2, pp. 445-487.

Kuznets, Simon. Shares of Upper Income Groups in Income and Savings. New York: National Bureau of Economic Research, 1953.

Kuznets, Simon. "Economic Growth and Economic Inequality", American Economic Review, March 1955, 45(1), pp.1-28.

Moriguchi, Chiaki and Saez, Emmanuel. "The Evolution of Income 
Concentration in Japan, 1885-2002: Evidence from Income Tax Statistics." University of California at Berkeley, Working Paper, August 2005.

Murphy, Kevin J. and Zábojník, Ján. "CEO Pay and Turnover: A Market Based Explanation for Recent Trends." American Economic Review, May 2004 (Papers and Proceedings), 94(2), pp. 192-196

Nolan, Brian. "Long-Term Trends in Top Income Shares in Ireland," in A. B. Atkinson and T. Piketty, eds., Top Incomes over the Twentieth Century, Oxford: Oxford University Press, 2006.

Piketty, Thomas. "Income inequality in France, 1901-1998." Journal of Political Economy, October 2003, 111(5), pp. 1004-1042.

Piketty, Thomas and Saez, Emmanuel. "Income Inequality in the United States, 1913-1998." Quarterly Journal of Economics, February 2003, 118(1), pp. 1-39.

Saez, Emmanuel and Veall, Michael R. "The Evolution of High Incomes in Northern America: Lessons from Canadian Evidence." American Economic Review, June 2005, 95(3), pp. 831-849. 
1 The present paper focuses mostly on US findings. The volume edited by Anthony Atkinson and Thomas Piketty (2006) gathers series for France, the United States, the United Kingdom, Canada, Australia, New Zealand, Ireland, Germany, Switzerland, the Netherlands, and India. Since then, preliminary series have been produced for Sweden, Finland, Japan, and Spain.

2 The first economist to use these data sources and methodology in a systematic way was Simon Kuznets (1953), who produced top income shares in the United States for the period 1913-1948. Simon Kuznets (1955) used those series to develop his famous inverted U-shape theory of the evolution of inequality during the process of development.

3 The negative effect of the wars on top incomes can be explained in part by the large tax increases enacted to finance the wars. During both wars, the corporate income tax (as well as the individual income tax) was drastically increased and this reduced mechanically the distributions to stockholders (see our discussion below)

${ }^{4}$ The case of Japan is interesting because series start in 1885, at the very beginning of the industrialization of Japan. The series show that income concentration in Japan was high before industrialization began, and did not increase much during the industrialization process from 1885 to 1935.

5 Japan and Germany experienced a dramatic decline in income concentration during WWII. Top income shares did not recover at all in Japan (Chiaki Moriguchi and Emmanuel Saez, 2005) but did so to some extent in Germany (Fabien Dell, 2006). A systematic comparison of tax systems in Japan and Germany in the post-war period could thus be informative.

${ }^{6}$ Indeed, in the United States, most of the real compensation increases have been captured by the top decile with really small gains of median wage compensation (lan Dew-Becker and Robert Gordon, 2005). 


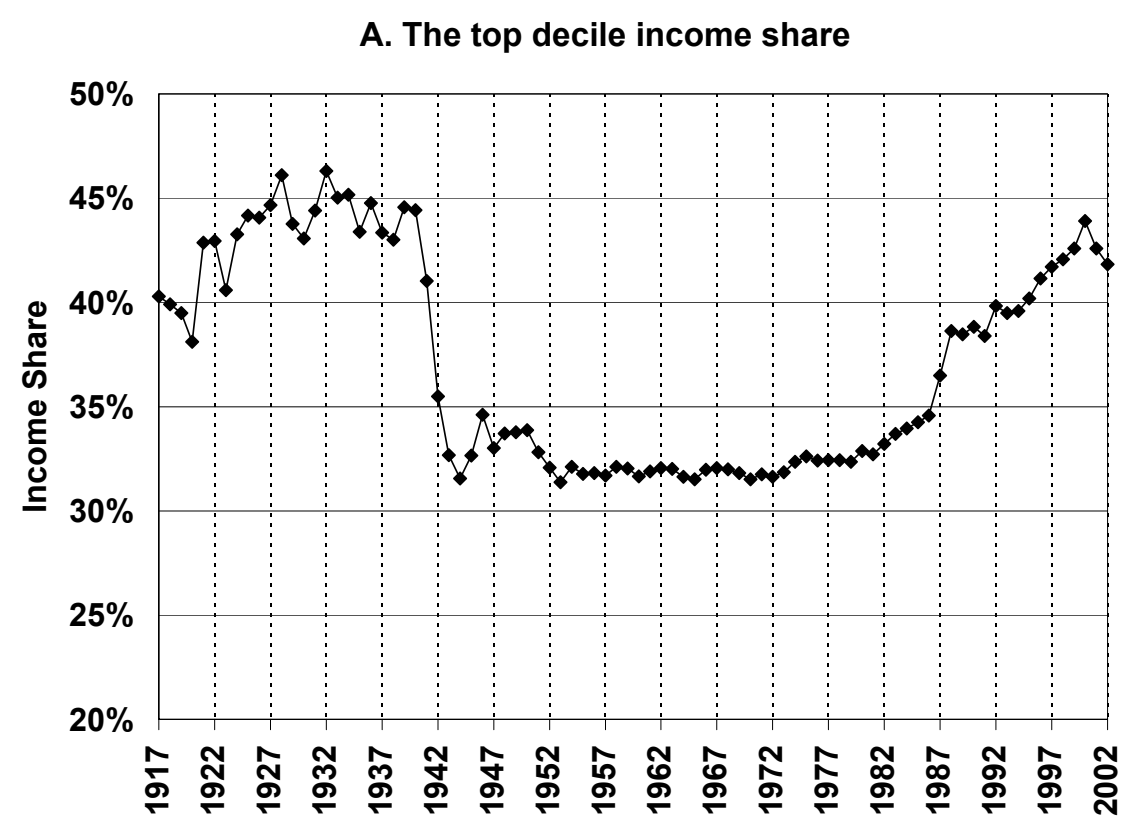

\section{B. Decomposing the top decile income share}

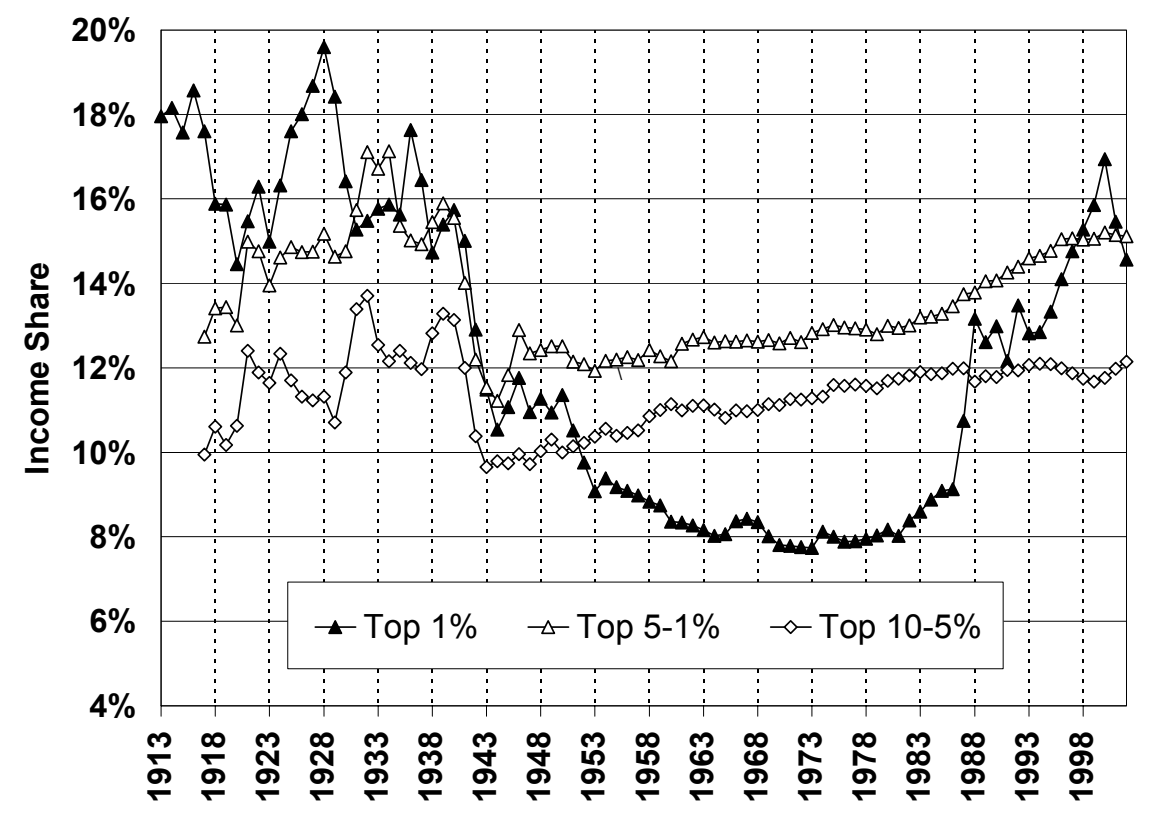

FIGURE 1.

Top Income Shares in the United States, 1913-2002

Source: Piketty and Saez $(2003,2006)$

Note: Income is defined as market income, excludes government transfers and realized capital gains. 


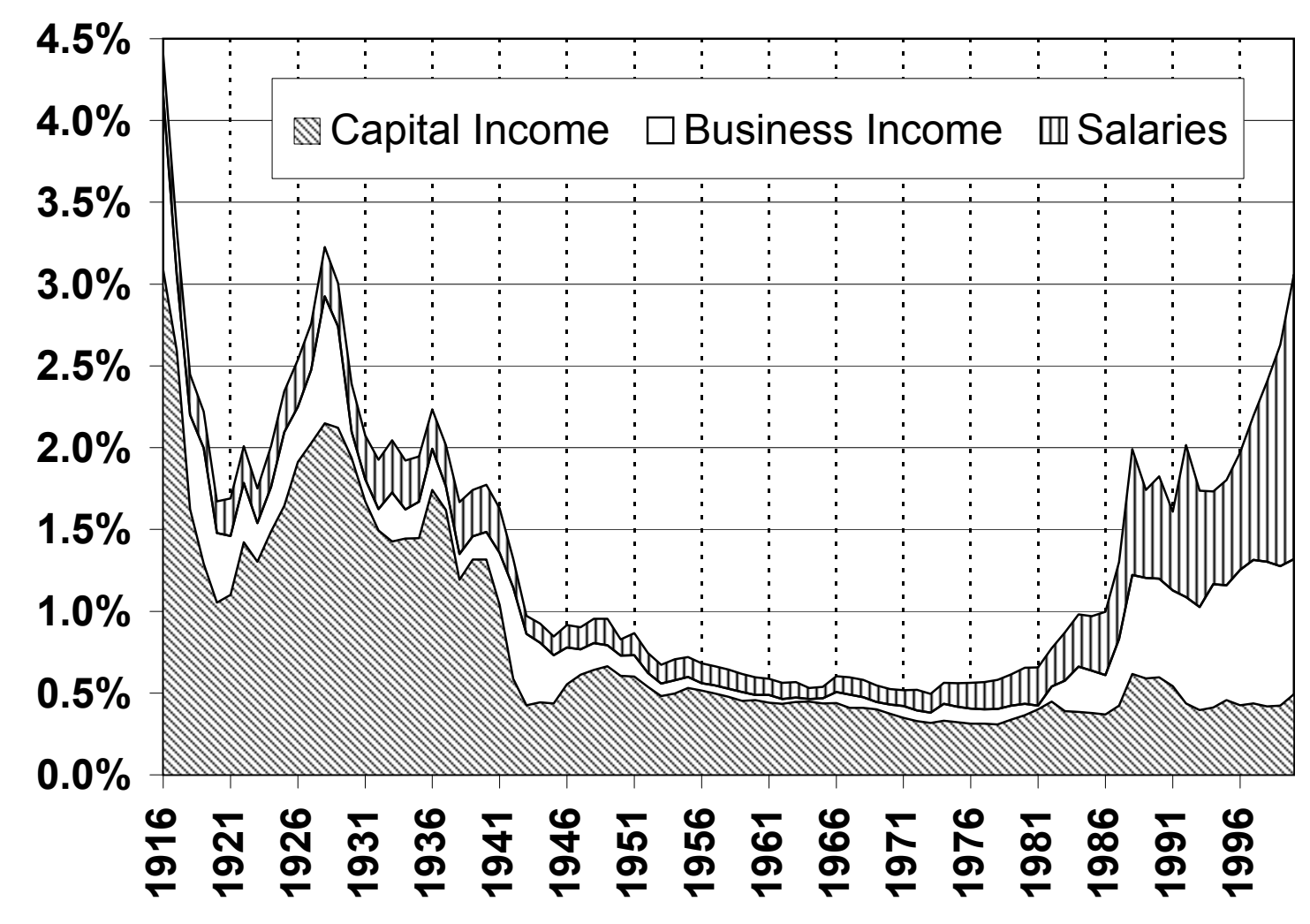

FIGURE 2.

The Top 0.01\% Income Share and Composition in the US, 1916-2000

Note: The Figure displays the top $0.01 \%$ income share (top curve) and its composition (excluding capital gains).

Source: Piketty and Saez $(2003,2006)$ 


\section{A. Top $0.1 \%$ incomne share in English Speaking Countries}

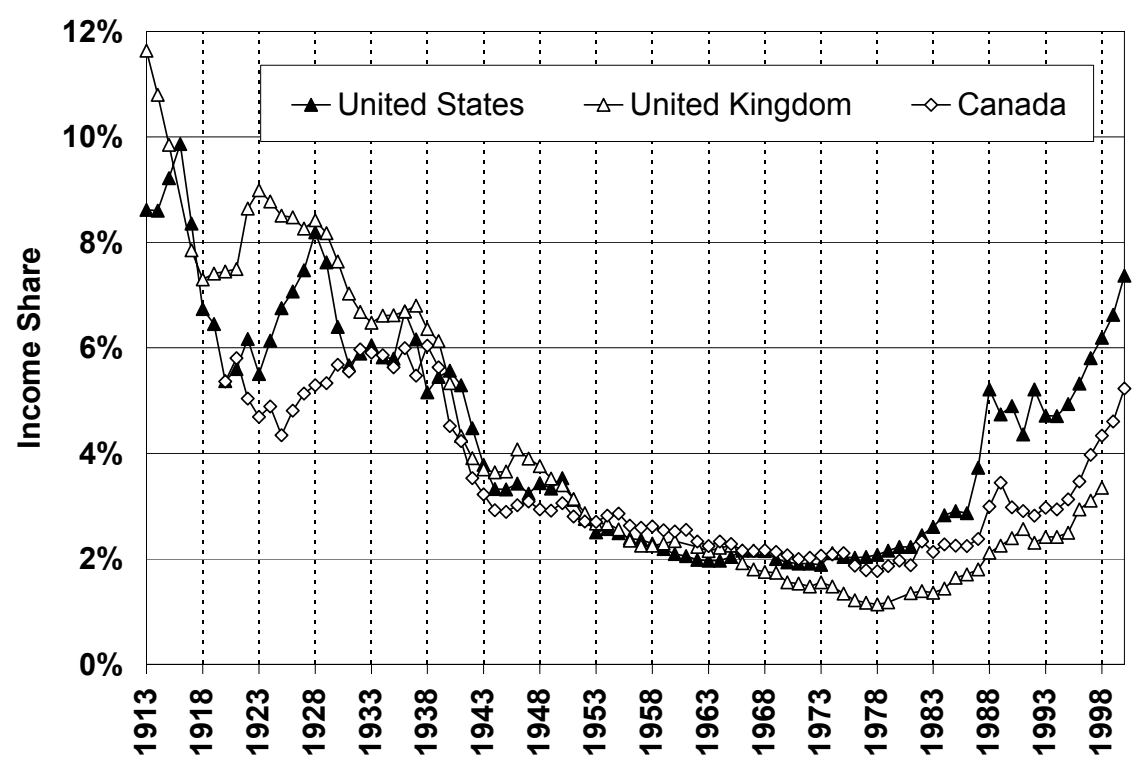

B. Top $0.1 \%$ income share in France and Japan

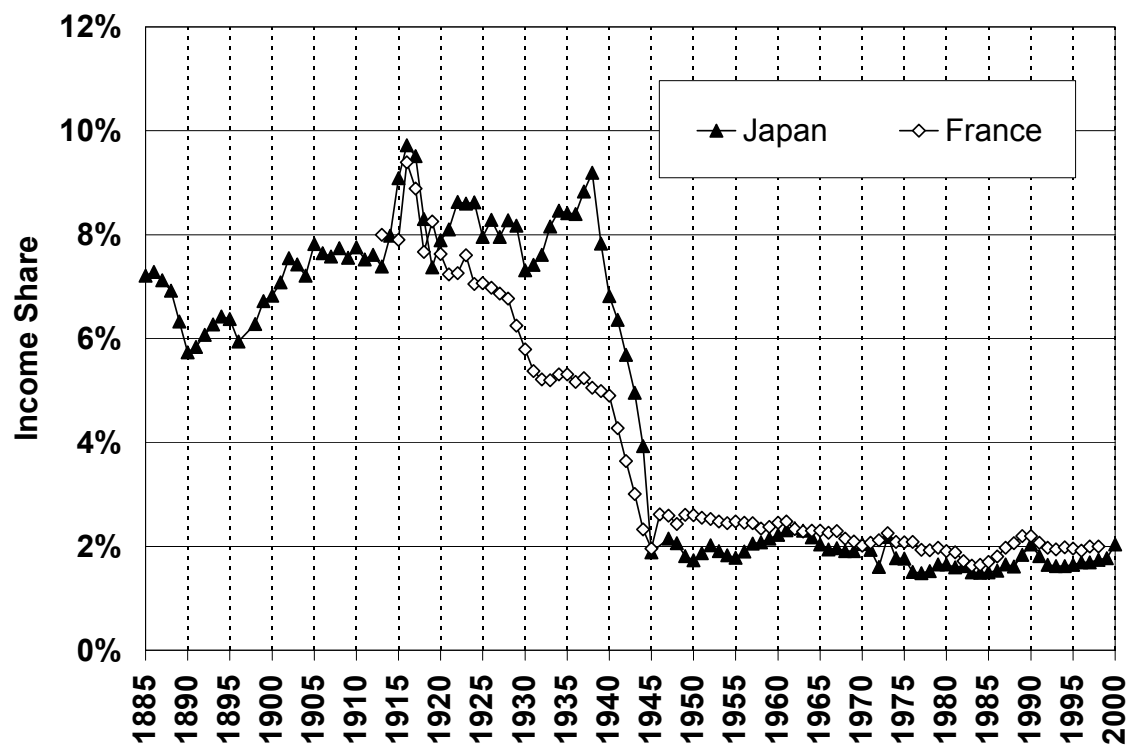

FIGURE 3.

Top $0.1 \%$ Income Shares across Countries

Source: United States, Piketty and Saez (2003, 2006); United Kingdom, Atkinson (2006);

Canada, Saez and Veall (2005); France, Piketty (2003); Japan, Moriguchi and Saez (2005). 


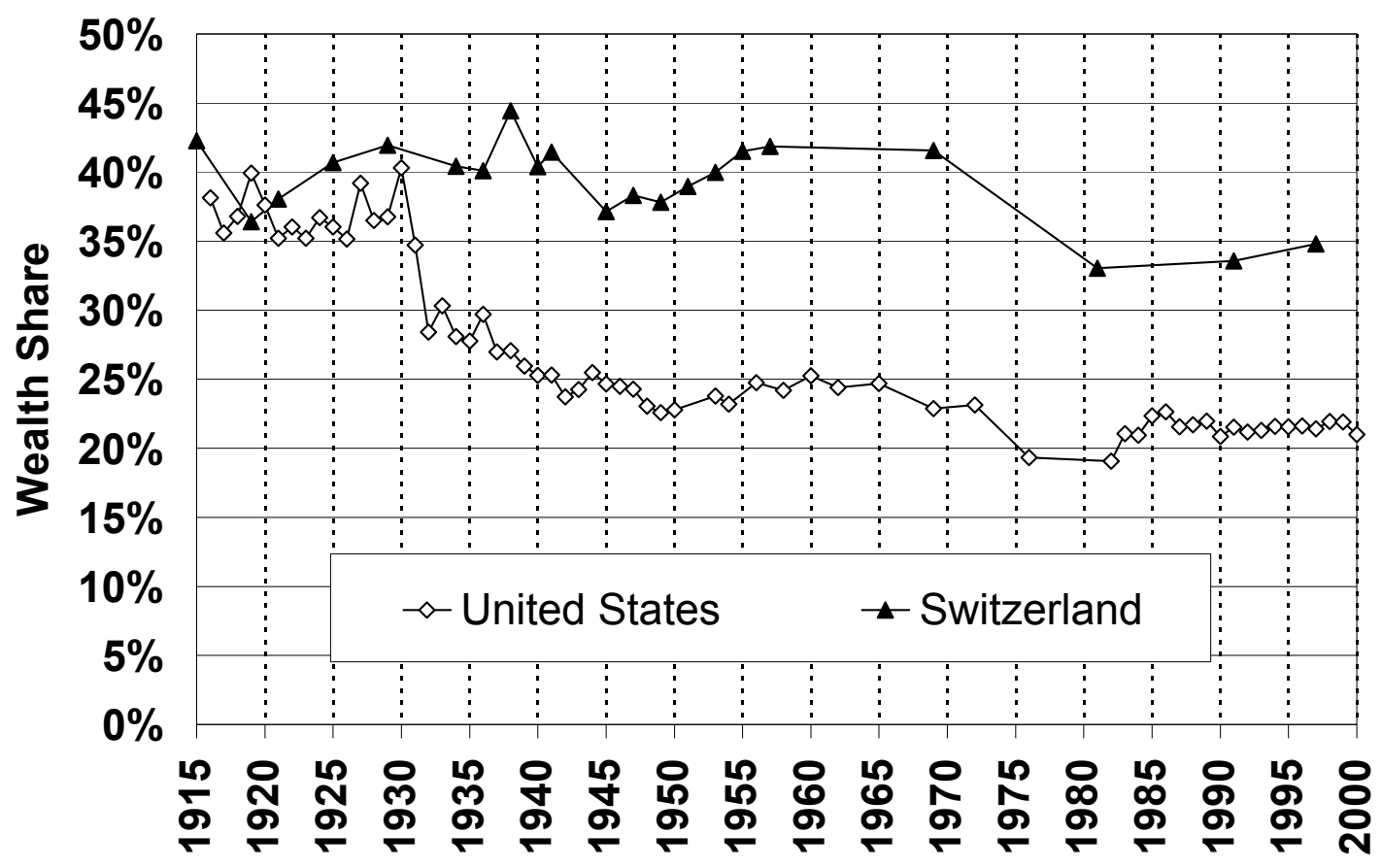

FIGURE 4.

Top 1\% Wealth Share in Switzerland and the United States

Source: United States, Kopczuk and Saez (2004); Switzerland, Dell, Piketty, and Saez (2006). 